\title{
RADIOCARBON DATING OF THE OLD ASH OF AITON, ROMANIA
}

\author{
ADRIAN PATRUT ${ }^{a, *}$, ROXANA T. PATRUT ${ }^{a, b}$, LASZLO RAKOSY $^{b}$, \\ ILEANA-ANDREEA RATIU ${ }^{a}$, DANIEL A. LOWY', \\ JENŐ BODIS ${ }^{a}$, KARL F. VON REDEN ${ }^{d}$
}

\begin{abstract}
The article reports the AMS (accelerator mass spectrometry) radiocarbon investigation results of the old common ash of Aiton. Five wood samples were collected from the trunk of the tree. The deepest ends of the samples were analysed by AMS radiocarbon. We found radiocarbon dates between $165 \pm 20 \mathrm{BP}$ and $240 \pm 18 \mathrm{BP}$, which correspond to calibrated ages of $230-360$ years. These results, combined with a ring counting estimate, indicate an age of $330 \pm 30$ years for the ash of Aiton. By this value, the ash of Aiton becomes the oldest known common ash with accurate dating results.
\end{abstract}

Keywords: AMS radiocarbon dating, Fraxinus excelsior, dendrochronology, age determination.

\section{INTRODUCTION}

The common ash, European ash or simply ash (Fraxinus excelsior L.) is a deciduous flowering tree that belongs to the Oleaceae family. The ash is native throughout mainland Europe occurring in $64 \%$ of European territories; its natural range largely coincides with that of the pedunculate oak. It is typically $20-30 \mathrm{~m}$ tall, exceptionally reaching $40-50 \mathrm{~m}$, and has a diameter up to $2 \mathrm{~m}$ [1-3].

\footnotetext{
a Babeş-Bolyai University, Faculty of Chemistry and Chemical Engineering, 11 Arany Janos, RO-400028, Cluj-Napoca, Romania.

b Babeş-Bolyai University, Faculty of Biology and Geology, 44 Republicii, RO-400015, ClujNapoca, Romania.

c Dept. of Science and Innovation, Valor Hungariae, 4 Nagysándor József, 1054 Budapest, Hungary.

' NOSAMS Facility, Dept. of Geology \& Geophysics, Woods Hole Oceanographic Institution, Woods Hole, MA 02543, U.S.A.

*Corresponding author: apatrut@gmail.com
} 

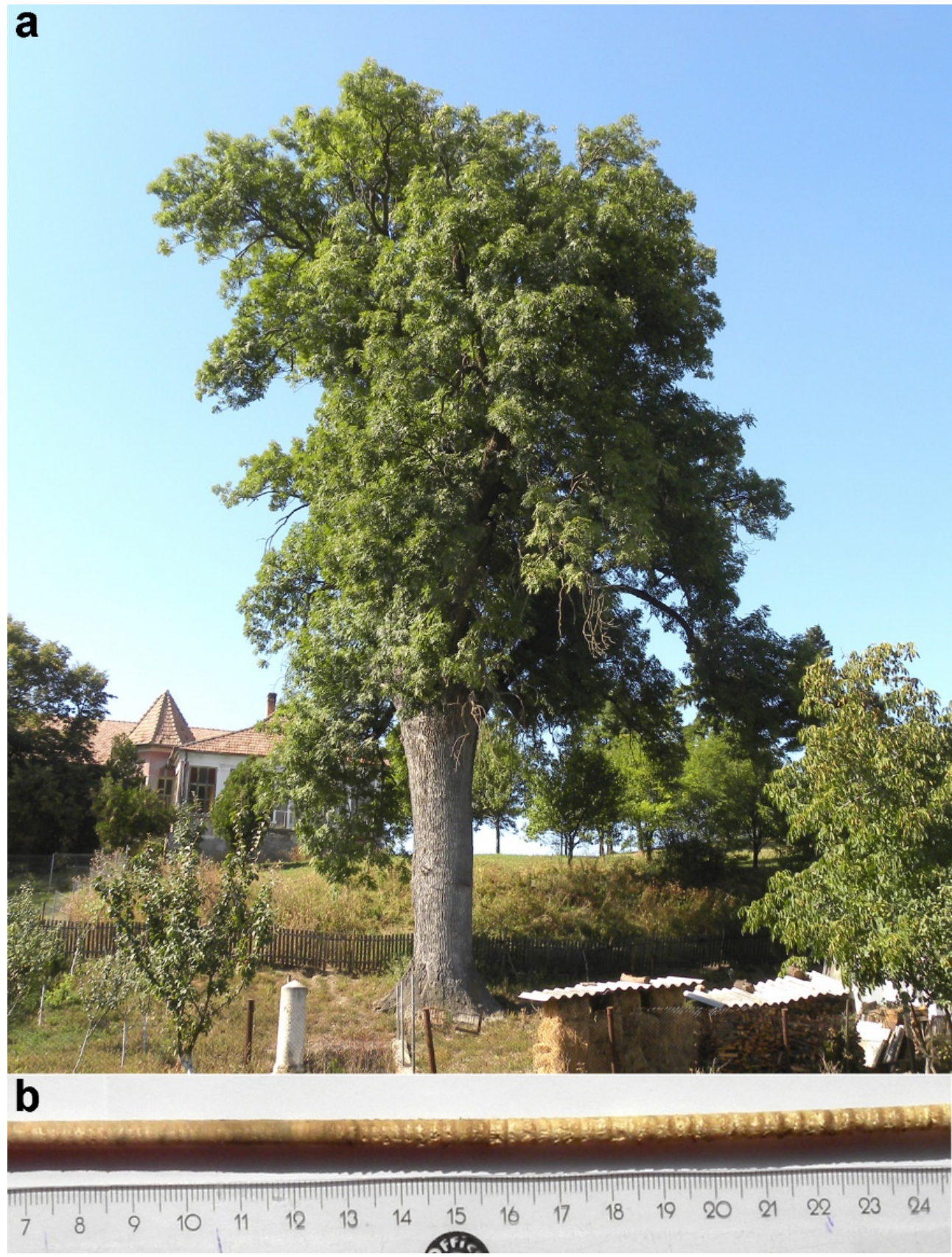

Figure 1. a. General view of the ash of Aiton.

b. Detail of sample 3, showing obvious and faint growth rings. 
In 2005, we started an in-depth research to elucidate several controversial or poorly understood aspects concerning the architecture, growth and age of the African baobab. The research is based on our new approach which enables to investigate and date standing live specimens, as well. This approach consists of AMS radiocarbon dating of tiny wood samples collected from different areas of such trees [4-9]. We extended our research by starting to date individuals which belong to other angiosperm species, including trees from Romania.

Romania hosts several monumental trees which have reached large dimensions and old ages. We investigated and dated by AMS radiocarbon some remains of the historic oak of Tebea [10], the large pedunculate oak of Cajvana [11], as well as the old black poplar of Mocod and the big grey poplar of Rafaila [12]. In each case we found very old ages for these species.

Here we disclose the AMS radiocarbon dating results of another representative Romanian tree, namely the old ash of Aiton.

\section{RESULTS AND DISCUSSION}

The old ash of Aiton and its area. The old ash is located in the garden of a privately-owned house (No. 420) in the village and commune Aiton, Cluj county, at $18 \mathrm{~km}$ SE of Cluj-Napoca, in the northern part of Romania. Its GPS coordinates are $46^{\circ} 40.949^{\prime} \mathrm{N}, 023^{\circ} 44.056^{\prime} \mathrm{E}$ and the altitude is $636 \mathrm{~m}$. The mean annual rainfall in the area is around $650 \mathrm{~mm}$.

The ash of Aiton has today a maximum height of $29.2 \mathrm{~m}$, the circumference at breast height (cbh; at $1.30 \mathrm{~m}$ above mean ground level) is $6.27 \mathrm{~m}$, while the circumference on slope at ground level is $11.65 \mathrm{~m}$. The overall wood volume is $32 \mathrm{~m}^{3}$, out of which the trunk/stem has a volume of $26 \mathrm{~m}^{3}$ (Figure 1a).

The quasi-cylindrical trunk forks at a height of 9.6-10.0 m into four large primary branches, with diameters up to $0.8 \mathrm{~m}$. Two other very large branches fell in 2005 and one in 2015 during storms, while other two branches burned down in 1994 in a big fire, after the tree was hit by lightning. The fire was only extinguished after 8 hours by firefighters; the fire damage reduced the canopy to the half and decreased the height of the ash. Now, the horizontal dimensions of the remaining canopy are $27.6(\mathrm{NS}) \times 23.6(\mathrm{WE}) \mathrm{m}$.

Wood samples. A number of five wood samples were extracted from the outer part of the tree around the circumference. The five samples (labelled 1 to 5) have lengths between 0.61 and $0.75 \mathrm{~m}$. The heights of the 
sampling points were between 1.70 and $2.01 \mathrm{~m}$. The deepest end of each sample (marked as a) was extracted for radiocarbon dating.

AMS results and calibrated ages. Radiocarbon dates of the deepest segments extracted from the five samples are listed in Table 1. Radiocarbon dates and errors were rounded to the nearest year. The radiocarbon dates are expressed in ${ }^{14} \mathrm{C}$ yr BP (radiocarbon years before present, i.e., before the reference year $A D$ 1950).

Calibrated (cal) ages, expressed in calendar years, are also shown in Table 1. The 1- $\sigma$ probability distribution was selected to derive calibrated age ranges. For all sample segments, the 1- $\sigma$ distribution corresponds to two, three or four ranges of calendar years. For these segments, the confidence interval of one range is considerably greater than that of the others; therefore, it was selected as the cal AD range of the segment for the purpose of this discussion. For obtaining single calendar age values of sample segments, we derived a mean calendar age of each segment from the selected range (marked in bold). Calendar ages of segments represent the difference between AD 2018 and the mean value of the selected range, with the corresponding error. Calendar ages and errors were rounded to the nearest $5 \mathrm{yr}$.

Table 1. AMS radiocarbon dating results and calibrated calendar ages of samples/segments collected from the Aiton ash.

\begin{tabular}{|c|c|c|c|c|}
\hline $\begin{array}{c}\text { Sample } \\
\text { (Segment) } \\
\text { code }\end{array}$ & $\begin{array}{c}\text { Depth }^{1} \\
{\left[\text { [height }^{2}\right]} \\
\left(10^{-2} \mathrm{~m}\right)\end{array}$ & $\begin{array}{c}\text { Radiocarbon date } \\
\text { [error] } \\
\left({ }^{14} \mathrm{C} \text { yr BP }\right)\end{array}$ & $\begin{array}{c}\text { Cal AD ranges } \\
1-\sigma \\
\text { [confidence interval] }\end{array}$ & $\begin{array}{c}\text { Sample age } \\
\text { [error] } \\
\text { (cal yr) }\end{array}$ \\
\hline $1 a$ & $\begin{array}{c}64 \\
{[195]}\end{array}$ & $170[ \pm 17]$ & $\begin{array}{c}1670-1682[12.4 \%] \\
1736-1780[42.8 \%] \\
1798-1804[5.6 \%] \\
1936-1944[7.4 \%]\end{array}$ & $260[ \pm 20]$ \\
\hline $2 a$ & $\begin{array}{c}71 \\
{[185]}\end{array}$ & $229[ \pm 19]$ & $\begin{array}{c}1653-1666[40.2 \%] \\
1784-1794[28.0 \%]\end{array}$ & $360[ \pm 5]$ \\
\hline $3 a$ & $\begin{array}{c}75 \\
{[201]}\end{array}$ & $240[ \pm 18]$ & 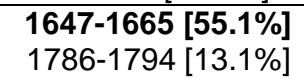 & $360[ \pm 10]$ \\
\hline $4 a$ & $\begin{array}{c}62 \\
{[170]}\end{array}$ & $205[ \pm 21]$ & $\begin{array}{c}1659-1675[18.9 \%] \\
1777-1799[32.1 \%] \\
1941-\ldots[17.3 \%]\end{array}$ & $230[ \pm 10]$ \\
\hline $5 a$ & $\begin{array}{c}61 \\
{[177]}\end{array}$ & $165[ \pm 20]$ & $\begin{array}{c}1673-1682[8.2 \%] \\
\mathbf{1 7 3 5 - 1 7 7 8}[\mathbf{4 2 . 9 \%}] \\
1799-1806[6.3 \%] \\
1930-1942[10.7 \%]\end{array}$ & $260[ \pm 20]$ \\
\hline
\end{tabular}

${ }^{1}$ Depth in the wood from the sampling point.

2 Height above ground level. 
Dating results of samples (segments). The deepest part/end of the collected samples have radiocarbon dates between $165 \pm 20$ BP and $240 \pm$ $18 \mathrm{BP}$. These values correspond to calibrated ages between $230 \pm 10$ and $360 \pm 10 \mathrm{yr}$.

One should mention that the calibration, i.e., the conversion of radiocarbon dates into calendar ages, can be discussed in particular cases. Thus, the calibration of wood samples which have calendar/dendro ages in the time frame AD 1640 - 1950 shows some uncertainties. In such cases, the calibration of one radiocarbon date may result in up to five or six calendar age ranges. This is due to the so-called "Suess effect", which expresses the high variation of the atmospheric radiocarbon concentration produced by the combustion of fossil fuels $[13,14]$.

Ring counting. On the collected wood samples, the growth/annual rings are obvious in certain areas, while in other areas they are very faint (Figure 1b). Therefore, an accurate ring counting is not possible. The longest sample 3 had a length of $0.75 \mathrm{~m}$ and was collected at a height of $2.01 \mathrm{~m}$. At this height, the circumference of the trunk is $5.50 \mathrm{~m}$. This value corresponds to a diametre of $1.72 \mathrm{~m}$ without bark. The distance from the sample end to the centre/theoretical pith is $0.11 \mathrm{~m}$.

We estimate that sample 3 contains around $300-320$ rings. By considering that the ash grows faster in the first 40 years [3], the number of missing rings from the sample end to the pith must be close to 20 . Therefore, this estimate for the ash of Aiton suggests a number of $320-340$ growth rings.

We investigated and measured the tree in 2009, 2010, 2013, 2015 and 2018. The mean growth rate over this period, namely the increase in radius, was of $1.9 \times 10^{-3} \mathrm{~m} \mathrm{yr}^{-1}\left(0.19 \mathrm{~cm} \mathrm{yr}^{-1}\right)$ at the height of $2 \mathrm{~m}$.

Age of the ash of Aiton. The radiocarbon dating results and the ring counting estimate indicate an age of $300-360 \mathrm{yr}$, i.e., $330 \pm 30 \mathrm{yr}$ for the investigated ash. By this value, the ash of Aiton becomes the oldest known common ash with accurate dating results and certainly one of the oldest common ash in Europe.

\section{CONCLUSIONS}

Our research discloses the AMS radiocarbon dating results of the old common ash of Aiton. The main aim of the research was to determine the age of tree. Five wood samples were collected from its trunk. The deepest 
ends of each sample were processed and dated by AMS radiocarbon. The five segments have radiocarbon dates between $165 \pm 20 \mathrm{BP}$ and $240 \pm 18$ $\mathrm{BP}$, which correspond to calibrated ages between $230 \pm 10$ and $360 \pm 10 \mathrm{yr}$. These results, combined with a ring counting estimate, indicate an age of $330 \pm 30 \mathrm{yr}$ for the ash of Aiton which has started growing around the year 1690.

\section{EXPERIMENTAL SECTION}

Metric measurements. The height of the tree was measured using a Bosch DLE 70 Professional laser rangefinder. The circumference at different heights was measured with graduated tapes. The volume was determined from laser measurements of the trunk and of large branches at different heights.

Sample collection. The five wood samples were collected with a Haglöf $\mathrm{CH} 800$ increment borer (80 cm length, $0.54 \mathrm{~cm}$ inner diameter). A number of five tiny pieces/segments of the length of $0.1 \mathrm{~cm}$ were extracted from the deepest end of each wood sample. The segments were processed and investigated by AMS radiocarbon dating.

Sample preparation. The standard acid-base-acid pretreatment method was used for removing soluble and mobile organic components. The pretreated samples were combusted to $\mathrm{CO}_{2}$ by using the closed tube combustion method. Next, $\mathrm{CO}_{2}$ was reduced to graphite on iron catalyst, under hydrogen atmosphere [15]. Finally, the resulting graphite samples were analysed by AMS.

AMS measurements. AMS radiocarbon measurements were performed at the NOSAMS Facility of the Woods Hole Oceanographic Institution (Woods Hole, MA, U.S.A.) by using the Pelletron ${ }^{\circledR}$ Tandem 500 kV AMS system. The obtained fraction modern values, corrected for isotope fractionation with the normalized $\delta^{13} \mathrm{C}$ value of $-25 \%$, were ultimately converted to a radiocarbon date.

Calibration. Radiocarbon dates were calibrated and converted into calendar ages with the OxCal v4.3 for Windows [16], by using the IntCal13 atmospheric data set [17]. 


\section{ACKNOWLEDGMENTS}

Authors thank Vasile and Mărioara Mureşan, the owners of the house Aiton 420 for granting the investigation and sampling of the old ash, as well as Flaviu Gherman for offering information about the tree. The research was funded by the Romanian Ministry of Research and Innovation CNCSUEFISCDI under grant PN-III-P4-ID-PCE-2016-0776, Nr. 90/2017.

\section{REFER E N C E S}

1. D. Dobrowolska, S. Hein, A. Oosterbaan, S. Wagner, J. Clark, J.P. Skovsgaard, Forestry, 2011, 84(2), 133.

2. P.A. Thomas, Journal of Ecology, 2016, 104, 1158.

3. K. Giagli, J. Baar, M. Fajstavr, V. Gryc, H. Vavrcik, BioResources, 2018, 13(1), 804.

4. A. Patrut, K.F. von Reden, D.A. Lowy, A.H. Alberts, J.W. Pohlman, R. Wittmann, D. Gerlach, L. Xu, C. Mitchell, Tree Physiology, 2007, 27, 1569.

5. A. Patrut, K.F. von Reden, R. Van Pelt, D.H. Mayne, D.A. Lowy, D. Margineanu, Annals of Forest Science, 2011, 68, 993.

6. A. Patrut, S. Woodborne, K.F. von Reden, G. Hall, M. Hofmeyr, D. Lowy, R.T. Patrut, PLOS ONE, 2015, 10(1), e0117193, doi: 10.1371/journal.pone.0117193.

7. A. Patrut, L. Rakosy, R.T. Patrut, I.A. Ratiu, E. Forizs, D.A. Lowy, D. Margineanu, K.F. von Reden, Studia UBB Chemia, 2016, LXI, 4, 7-20.

8. A. Patrut, S. Woodborne, K.F. von Reden, G. Hall, R.T. Patrut, L. Rakosy, P. Danthu, J-M. Leong Pock-Tsy, D.A. Lowy, D. Margineanu, Radiocarbon, 2017, 59(2), 435.

9. A. Patrut, S. Woodborne, R.T. Patrut, L. Rakosy, D.A. Lowy, G. Hall, K.F. von Reden, Nature Plants, 2018, 4, 423.

10. A. Patrut, K.F. von Reden, D.A. Lowy, S. Pasca, L. Kekedy-Nagy, I. Sovago, Studia UBB Chemia, 2010, 55, 1, 113.

11. A. Patrut, K.F. von Reden, V. Savu, D.A. Lowy, R. Mitea, I. Barbul, Studia UBB Chemia, 2011, 56, 1, 145.

12. A. Patrut, K.F. von Reden, D.A. Lowy, R.T. Patrut, D.L. Vaida, D. Margineanu, Nuclear Instruments and Methods in Physics Research Section B, 2013, 294, 616.

13. P.P. Tans, A.F.M. de Jong, W.G. Mook, Nature, 1979, 280, 826. 
14. M. Worbes, Dendrochronologia, 2002, 20 (1-2), 217-231.

15. A. Patrut, S. Woodborne, R.T. Patrut, L. Rakosy, G. Hall, I.A. Ratiu, K.F. von Reden, Studia UBB Chemia, 2017, LXII, 2, 347.

16. C. Bronk Ramsey, Radiocarbon, 2009, 51, 337.

17. P.J. Reimer, E. Bard, A. Bayliss, J.W. Beck, P.G. Blackwell, C. Bronk Ramsey, C.E. Buck, H. Cheng, R. Lawrence Edwards, M. Friedrich, P.M. Grootes, T.P. Guilderson, H. Haflidason, I. Hajdas, C. Hatte, T.J. Heaton, D.L. Hoffman, A.G. Hogg, K.A. Hughen, K.F. Kaiser, B. Kromer, S.W. Manning, M. Niu, R.W. Reimer, D.A. Richards, E.M. Scott, J.R. Southon, R.A. Staff, C.S.M. Turney, J. van der Plicht, Radiocarbon, 2013, 55(4), 1869. 